Paper:

\title{
Tsunami Inundation Mapping in Lima, for Two Tsunami Source Scenarios
}

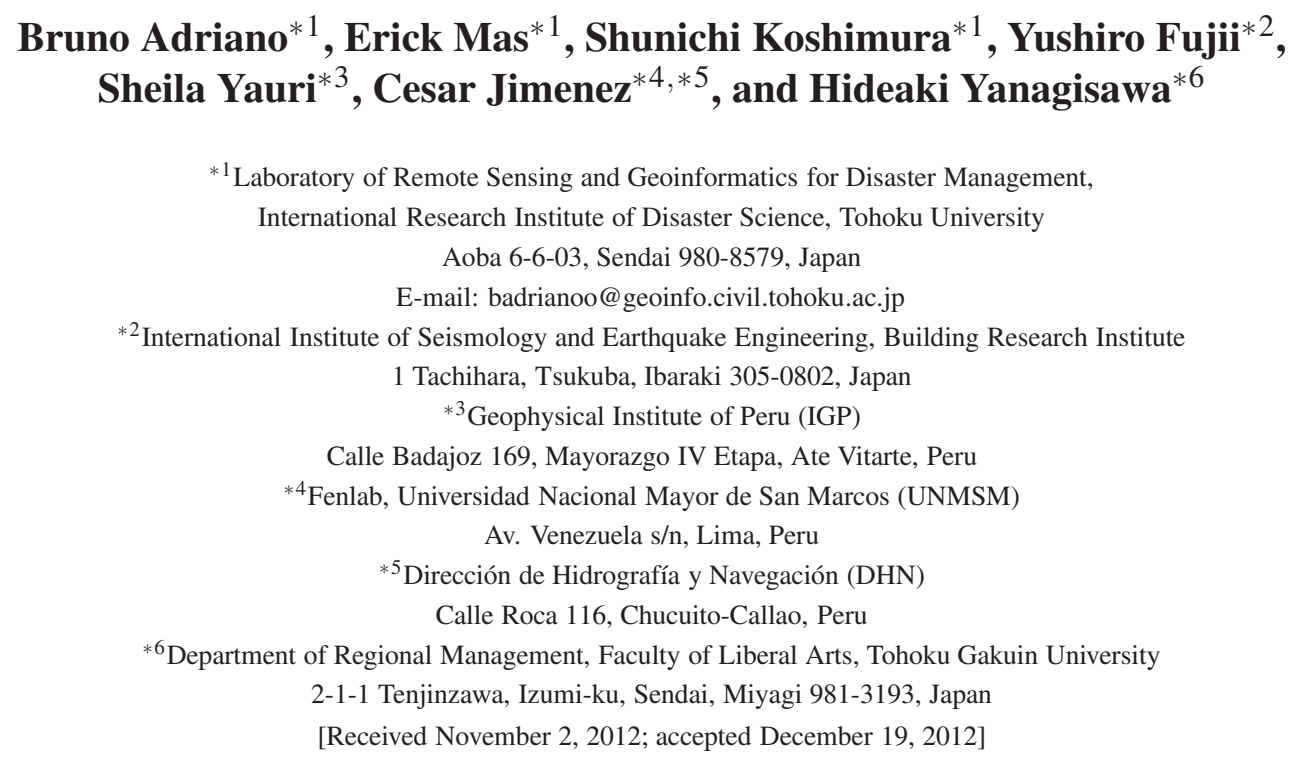

Within the framework of the project Enhancement of Earthquake and Tsunami Disaster Mitigation Technology in Peru (JST-JICA SATREPS), this study determines tsunami inundation mapping for the coastal area of Lima city, based on numerical modeling and two different tsunami seismic scenarios. Additionally, remote sensing data and geographic information system (GIS) analysis are incorporated in order to improve the accuracy of numerical modeling results. Moreover, tsunami impact is evaluated through application of a tsunami casualty index (TCI) using tsunami modeling results. Numerical results, in terms of maximum tsunami depth, show a maximum inundation height of $6 \mathrm{~m}$ and $\mathbf{1 5 . 8} \mathrm{m}$ for a potential scenario (first source model) and for a past scenario (second source model), respectively. In terms of inundation area, the maximum extension is $1.3 \mathrm{~km}$ with a runup height of $5.3 \mathrm{~m}$ for the first scenario. The maximum extension is $2.1 \mathrm{~km}$ with a runup height of $11.4 \mathrm{~m}$ for the second scenario. The average TCI value obtained for the first scenario is 0.36 for the whole inundation domain. The second scenario gives a mean value of 0.64 , where TCI equal to $\mathbf{1 . 0 0}$ represents the highest condition of risk. The results presented in this paper provide important information about understanding tsunami inundation features and, consequently, may be useful in designing an adequate tsunami evacuation plan for Lima city.

Keywords: inundation modeling, inundation mapping and casualty index

\section{Introduction}

Tsunami inundations have caused an unfortunate loss of life and extensive property damage to coastal communities in seismic-prone countries. Tsunami events that occurred in seismically similar areas such as the 2010 Chile Tsunami, the 2012 Japan Tsunami and the December 26, 2004, Sumatra tsunami, for instance, are tragic reminders of the devastation that these powerful events can generate in coastal areas. In the case of Peruvian seismic history, one of the most disastrous seismic events occurred in 1746, whose epicenter was located in front of the central area of Peruvian coast. According to historical testimony, the capital city of Lima was completely destroyed by ground shaking and the subsequent tsunami flood [1]. It is therefore important to develop an efficient tsunami warning system in order to mitigate the catastrophic damage due to tsunami events.

Detailed maps of potential tsunami inundation areas are important for the delineation of evacuation routes and long-term planning in vulnerable coastal communities. The Dirección de Hidrografía y Naveagación (DHN) [2] is the Peruvian institution responsible for the Sistema Nacional de Alerta de Tsunamis (SNAT The national tsunami warning system). This institution publishes and periodically updates inundation charts for main coastal cities and ports along the whole Peruvian coast. These inundation charts are mostly developed by using tsunami refraction curves technique that estimates tsunami arrival time and tsunami height along the coastline through progressive curves that are drawn from the epicenter and empirical equations, respectively. This methodology is explained in [3], [4] and [5]. Additionally, the inundation 


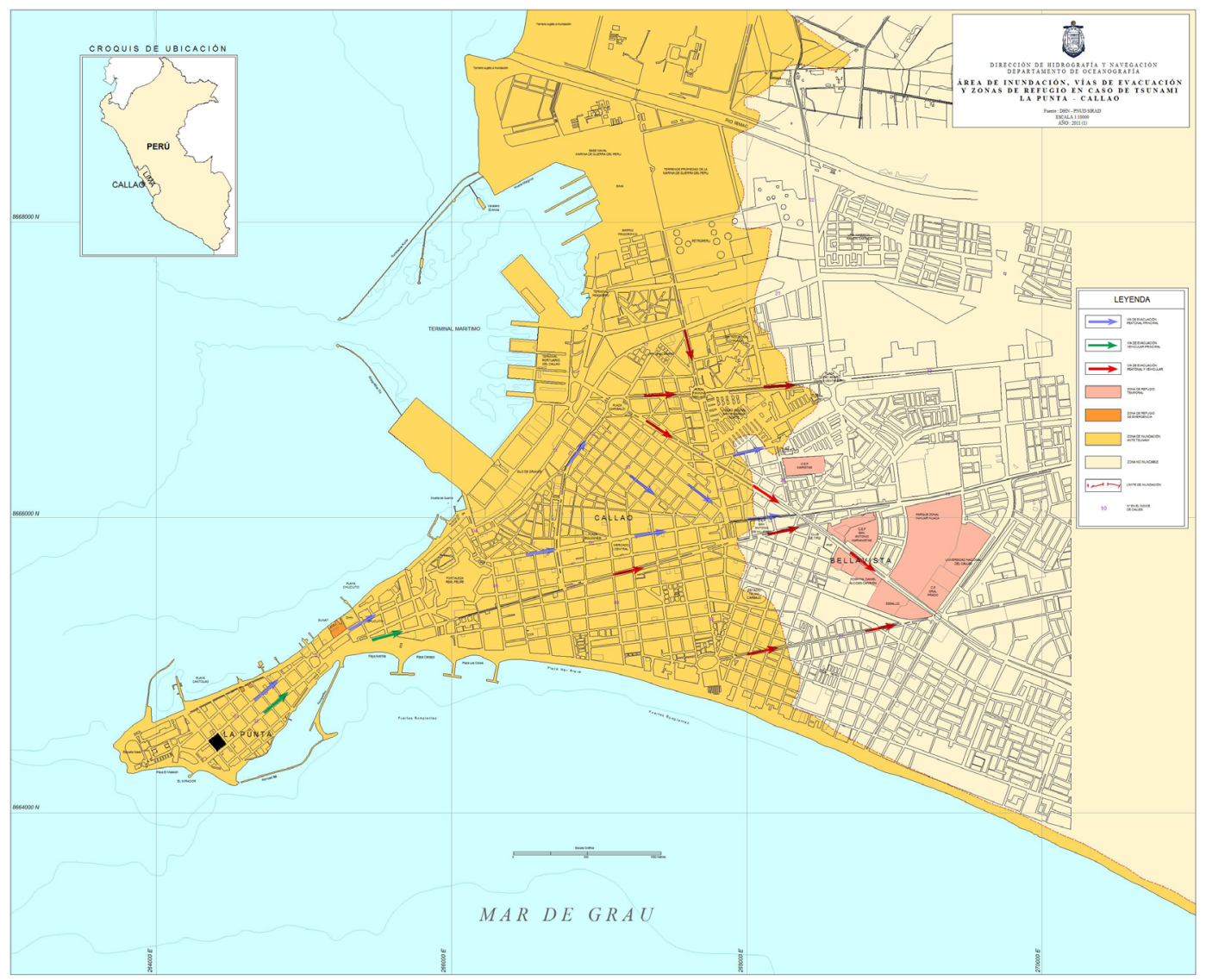

Fig. 1. Inundation chart published by DHN for the La Punta district and Callao Province [2].

chart that covers the La Punta district and part of Callao Province (see Fig. 1) was updated within the framework of the project Sistema de Información Sobre Recursos para Atencion de Desastres [6]. The inundation zone indicated in this inundation chart is the result of the worstcase scenario chosen from two different seismic sources models and was calculated using the Tsunami Inundation Modeling Exchange (TIME project) [7]. Fig. 1 shows the inundation chart for La Punta and Callao.

The purpose of this study is to determine the tsunami inundation area for the coastal region of Lima city by adopting two different seismic source scenarios through numerical modeling and a detailed topography model that includes building height information and land use classification. Additionally, numerical modeling results such as flow depths and current velocity are used to evaluate tsunami impact by estimating a tsunami casualty index within the inundation area.

\section{Description of the Study Area}

The study area essentially covers the central zone of the Lima coast that corresponds to the constitutional province of Callao (see Fig. 2). The geographic limits for the study area are $11.95^{\circ}-12.09^{\circ}$ south and $77.18^{\circ}$ to $77.13^{\circ}$ west. Morphologically, the coastal plain rises to approximately $15 \mathrm{~m}$ above sea level near the shoreline. While the coast- line to the north forms a long sweeping bay, however, the coastline to the south of the study area presents a small peninsula that corresponds to the La Punta district. According to the Peruvian Institute of Statistic and Informatics [8] (INEI), the population of Lima city is about 9 million people. For Callao province, however, there are about 950,000 living in this province. Urban use in the study area is divided mainly into three types (see Fig. 2c). The first corresponds to residential type, with its area concentrated in the southern part of the inundation domain below $12^{\circ} 02^{\prime} 30^{\prime \prime} \mathrm{S}$. This is the most populated area in Callao province and as a result, the land surface is largely covered by houses and avenues. The second urban use is located in the center of the study area between $12^{\circ} 01^{\prime} \mathrm{S}$ and $12^{\circ} 02^{\prime} 30^{\prime \prime} \mathrm{S}$. This zone is covered by extensive vegetated area that corresponds to the back of the International Airport of Lima and agricultural fields. There are also some towns along the coastline, where housing types are principally non engineering buildings [8]. In the third zone type, the land surface along the coastline is mainly occupied by factories.

\section{Tsunami Source Scenario}

Seismic events accompanied by large tsunamis along coastal central Peru have been reported since historical times. The 1746 earthquake, for instance, is considered 

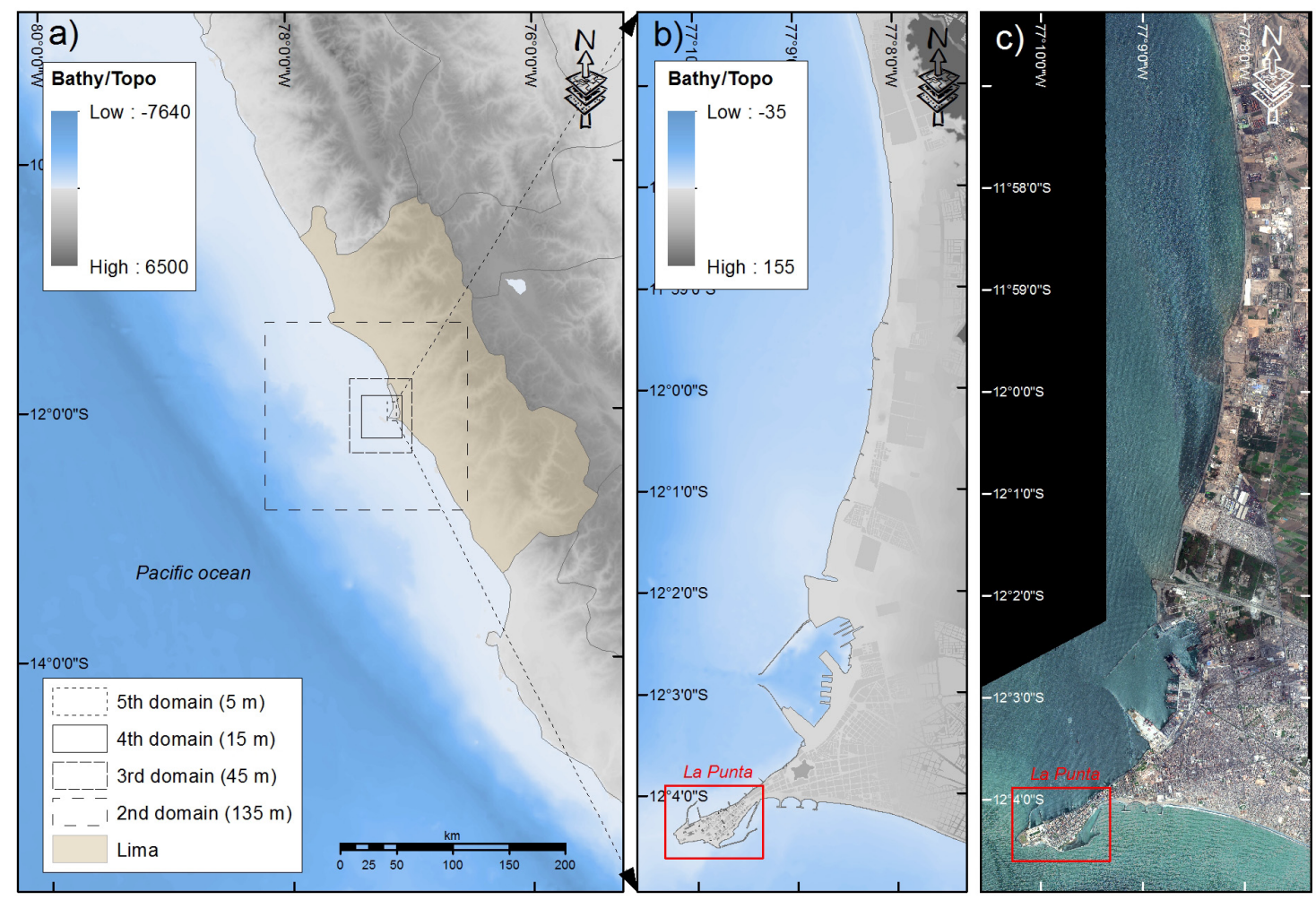

Fig. 2. a) View of the first domain ( $405 \mathrm{~m}$ grid resolution). Boundaries for other domains are shown in dashed lines. b) View of bathymetry and topography datasets for inundation modeling $\left(5^{\text {th }}\right.$ domain). c) Study area that corresponds to the $5^{\text {th }}$ domain, background view of WorldView-2 satellite images in true composite.

one of the most catastrophic seismic events in Peruvian history. The moment magnitude for this event has been estimated between 8.8 and 9.0 and the reported tsunami runup height was between $15 \mathrm{~m}$ and $24 \mathrm{~m} \mathrm{[1,9].} \mathrm{Two}$ centuries later, only two event with considerable magnitude have occurred. The 1966 earthquake, whose epicenter was located in the north central coastal area of Peru, had a rupture length of $100 \mathrm{~km}$ and a local tsunami height of $2.6 \mathrm{~m}$. The last, the 1974 earthquake that occurred in front of Lima city, had a rupture length of $140 \mathrm{~km}$ and a local tsunami height of $1.6 \mathrm{~m} \mathrm{[1]}$. No large earthquakes have been reported in the area since then. There is therefore a clear seismic gap of approximately 250 years. Furthermore, considering the seismic history of this area, it is urgent to take into account the high possibility of the occurrence of an enormous seismic event accompanied by a catastrophic tsunami in front of Lima city.

In the evaluation of seismic models, the application of global positioning system (GPS) observation and Interferometry Synthetic Aperture Radar (InSAR) makes it possible to measure strain/displacement associated with plate convergence movement in high-seismicity zones. [10] used a GPS array with about 1,000 permanent stations to recognize coseismic deformations associated with large earthquakes and ongoing deformation over long years in Japan. [11] and [12] used pre- and post event SAR imagery datasets to estimate crustal movement from the 2008 Wenchuan, China, earthquake and the 2011 To- hoku, Japan, earthquake, respectively. Historical information such as earthquake intensity perception, runup measurement and wave arrival times in past earthquake events plays an important role in estimating seismic models for potential earthquake scenarios that can be used to evaluate possible future impact [13]. In this study, the source model is based on two different seismic scenarios. The first is a megathrust earthquake that would likely adversely affect the metropolitan Lima region and that is appropriate for the simulation of long-period wave and tsunami modeling [14]. The seismic source is based on a model of interseismic coupling distribution in subduction areas for a period of 265 years since the 1746 earthquake. This data also includes sea floor deformation measurements obtained offshore from Lima city by a combination of GPS receivers and acoustic transponders [15], as well as information on historical earthquakes, to propose a slip distribution. The seismic source is divided into 280 sub fault segments, each $20 \mathrm{~km} \times 20 \mathrm{~km}$, in a $700 \mathrm{~km}$ by $160 \mathrm{~km}$ rupture area with a moment magnitude of 9.0 Mw. The slip solution model shows two main asperities, the largest approximately $70 \mathrm{~km}$ west of Lima city with maximum slip of $15.4 \mathrm{~m}$, and the second south of Lima with slip up to $13.0 \mathrm{~m}$. Fig. 3a shows the spatial location for slip model distribution. The second seismic scenario is a model of the tsunami source of the 1746 Peru earthquake that was calculated through a direct comparison of tsunami modeling results and the interpretation of 

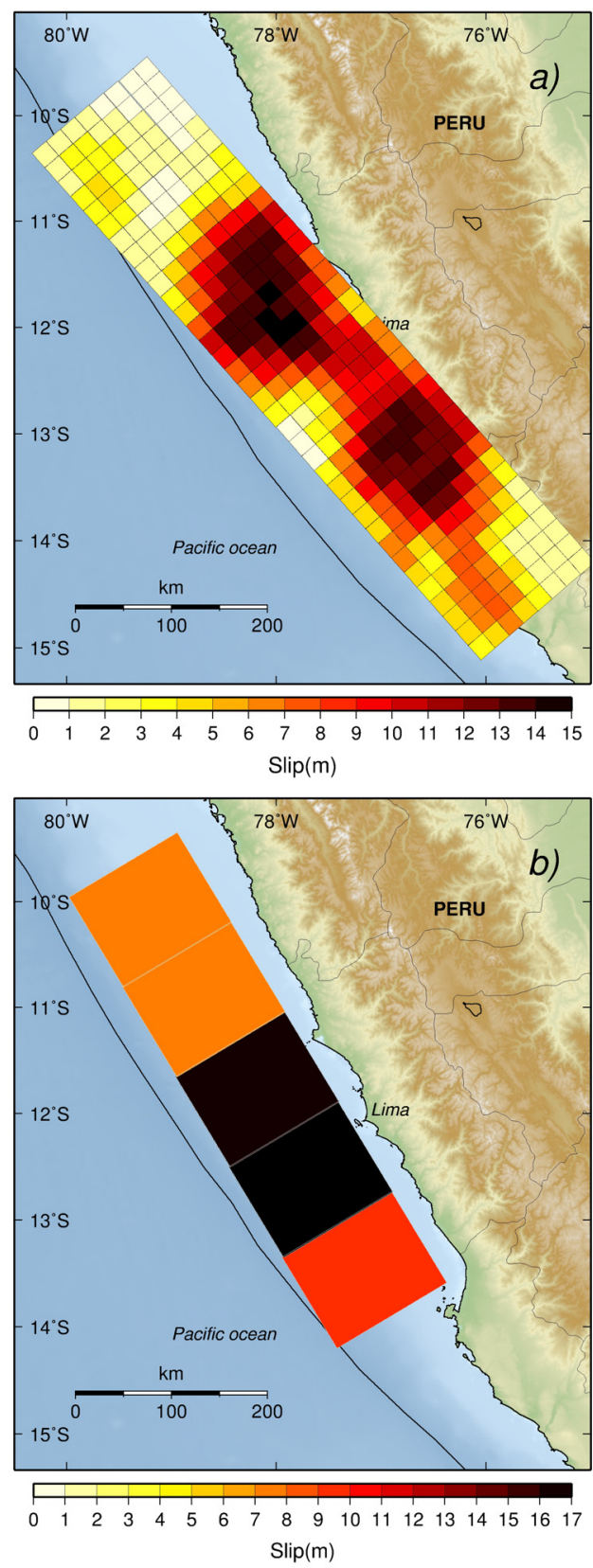

Fig. 3. a) Slip distribution proposed by [14] used for the first seismic scenario. b) Slip distribution proposed by [16] for the second scenario. The slip scale is shown below for each model.

historical documents about tsunami flooding [16]. This scenario estimates a $550 \mathrm{~km} \times 140 \mathrm{~km}$ rupture area for five sub fault models with a $110 \mathrm{~km} \times 140 \mathrm{~km}$ area. This model considers maximum slip of $17.5 \mathrm{~m}$ approximately $50 \mathrm{~km}$ southwest in front of Lima city. Fig. 3b shows slip model distribution for this seismic scenario.

\subsection{Initial Sea Floor Displacement}

We use a rectangular dislocation model [17] to calculate ocean bottom deformation due to our source scenarios. Initial sea floor displacement is assumed from the instant push up of seismic deformation on the ocean bot- tom. Features of the bottom deformation thus reflect initial water surface displacement that is assumed as an initial condition of tsunami propagation modeling. Fig. 4a shows displacement result for the first source scenario and Fig. $\mathbf{4 b}$ results for the second source scenario. Areas in red and blue represent uplift and subsidence displacement, respectively. Contour lines are drawn at $0.25 \mathrm{~m}$ intervals. In the case of the first scenario, there are two regions of high uplift deformation that are consistent with slip model distribution. The higher uplift region has a maximum displacement of $4.6 \mathrm{~m}$ and is located about $150 \mathrm{~km}$ in front of Lima coastal area. In the case of the second scenario, displacement distribution shows a homogeneous uplift area that is concentrated at the center of the rupture fault with a maximum displacement of about $8.2 \mathrm{~m}$.

\section{Tsunami Numerical Modeling}

Numerical simulation was conducted by using the Tohoku University Numerical Analysis Model for Investigation of Near-field tsunami No.2 (TUNAMI-N2) code based on shallow water theory and a Cartesian coordinate system that was developed by the Disaster Control Research Center (DCRC), Tohoku University, Japan. The set of nonlinear shallow water equations (Eqs. (1), (2) and (3)) are discretized using a staggered leap-frog finite difference scheme [18],

$$
\begin{aligned}
& \frac{\partial \eta}{\partial t}+\frac{\partial M}{\partial x}+\frac{\partial N}{\partial y}=0 \ldots . . . . . . \\
& \frac{\partial M}{\partial t}+\frac{\partial}{\partial x}\left(\frac{M^{2}}{D}\right)+\frac{\partial}{\partial y}\left(\frac{M N}{D}\right)= \\
& -g D \frac{\partial \eta}{\partial x}-\frac{g n^{2}}{D^{7 / 3}} M \sqrt{M^{2}+N^{2}} \quad . . \\
& \frac{\partial N}{\partial t}+\frac{\partial}{\partial x}\left(\frac{M N}{D}\right)+\frac{\partial}{\partial y}\left(\frac{N^{2}}{D}\right)= \\
& -g D \frac{\partial \eta}{\partial y}-\frac{g n^{2}}{D^{7 / 3}} N \sqrt{M^{2}+N^{2}} \quad . . \\
& M=\int_{-h}^{\eta} u d z \\
& M=\int_{-h}^{\eta} v d z \ldots \ldots \ldots \\
& D=\eta+h
\end{aligned}
$$

where $M$ and $N$ are the discharge flux in the $x$ - and $y$ directions, respectively; $\eta$ is the water level and $h$ is the water depth with respect to mean sea level.

To perform tsunami inundation modeling, the computational area is divided into five domains to construct a nested grid system (see Fig. 2). Bathymetry/topography data for the first and second domains are resampled from General Bathymetry Chart of the Ocean (GEBCO) 30 arc- 

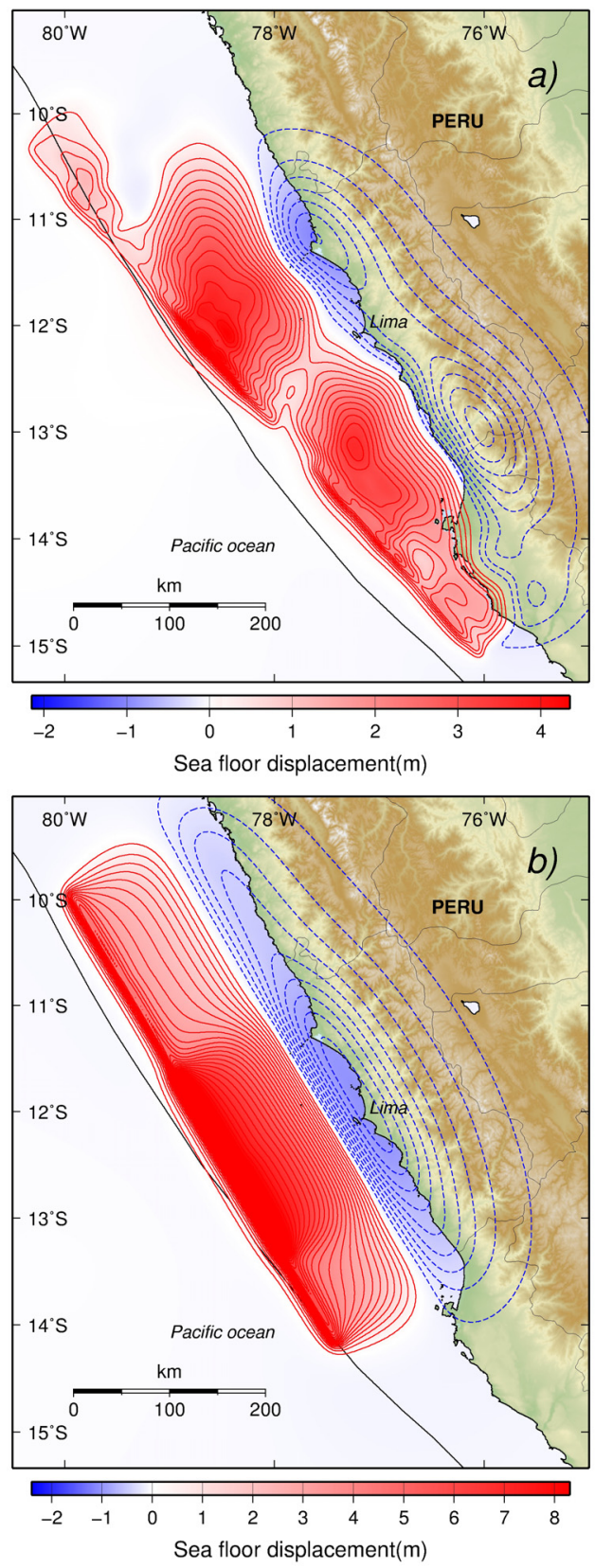

Fig. 4. a) Sea floor displacement calculated from the proposed slip distribution in the first source scenario. b) Sea floor displacement calculated from the estimated slip distribution [16]. Areas in red represent the uplift. Areas in blue represent subsidence displacement. Contour lines are drawn at $0.25 \mathrm{~m}$ intervals for each model.

seconds grid data. Bathymetry data for the third to fifth domains are constructed from a nautical chart provided by DHN and topography data are merged from the Thermal Emission and Reflection Radiometer (ASTER) 1 arcsecond resolution raster data and $5 \mathrm{~m}$ resolution contour line data from the Callao regional government. The grid size varies from $405 \mathrm{~m}$ to $5 \mathrm{~m}$.

\subsection{Roughness Coefficient for Inundation Zone}

Generally, based on the relation between the scale of an obstacle and the grid size of the computational domain, there are basically two approaches to be applied in inundation modeling [19]. The first is a topography model that uses a constant roughness coefficient for the whole computational domain and a very detailed topography dataset including building height informations. This approach is used when the obstacle or urban use, e.g., buildings, seawalls, roads or fields, is represented adequately within cells in the inundation model. This model thus uses a finer grid size where flow around and between obstacles is well simulated. The second approach is known as the equivalent roughness model, applied when obstacles are much smaller than grid size. [20] introduced an appropriate methodology for this case that is based on the calculation of a building/house occupation ratio within grid cells in the inundation domain. This method has been utilized and validated through a comparison with field survey data in order to develop tsunami fragility functions [21,22]. Furthermore, based on these methodologies, [23] presented a comparison of three runup models -a constant roughness model, a topography model and an equivalent roughness model- in highly populated areas. They concluded that the topographic model is used to identify the distribution of inundation parameters in residential areas.

Since high grid resolution and urban use influence the estimation bottom roughness coefficient, it may change the propagation of waves considerably due to obstacles or roughness induced energy dissipation. Consequently, the final input raster should include features with appropriate elevation heights and adequate roughness surface mapping [24]. In this study, in order to improve the accuracy of numerical results, we enhanced the topography model approach by adding a specific bottom roughness coefficient for each grid cell in the inundation domain. These coefficient values are based on a roughness coefficient map (see Fig. 5a). [25] performed land use classification using satellite images from WorldView-2 sensor. Coefficient values are assigned according to land use [26] in order to present a roughness coefficient map for the coastal area of Lima city. Additionally, topography data is combined with a height building model (see Fig. 5b). For the La Punta district, a GIS building shape file on a single house scale is available that includes the number of stories, spatial location and construction material type fields. In this case, the height building model is constructed by multiplying the number of stories by $2.5 \mathrm{~m}$, the standard story height in Lima city. For the rest of the computational domain, however, only the spatial location for a block scale is available. Nevertheless, in order to construct the height building model, we assume a two-story height for each block as a preliminary estimation. Only the historical building known as "Fortaleza Real Felipe" (location coordinates $-77.15 \mathrm{~W},-12.06 \mathrm{~S}$ ) was manually delineated, however, and its height is fixed equal to $8 \mathrm{~m}$, which is approximately the real height of the perimeter wall. Fig. 5 shows a roughness coefficient map and the final topography model use for inundation modeling. 


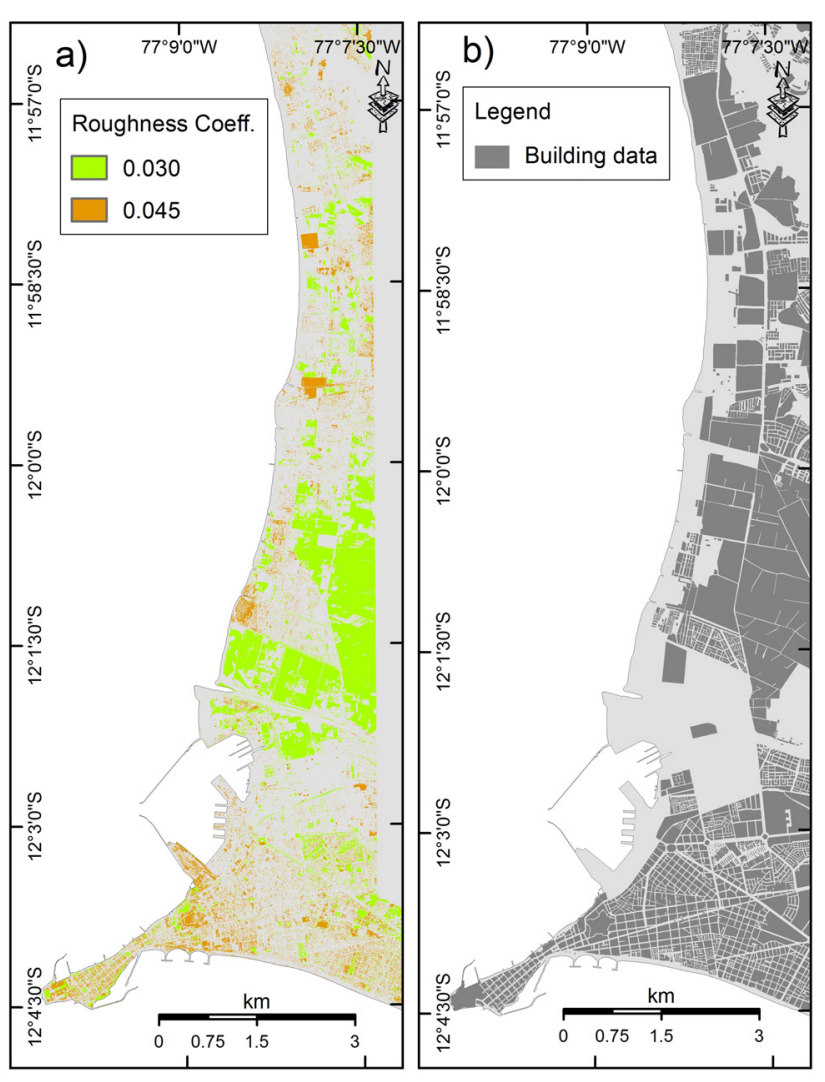

Fig. 5. a) Roughness coefficient map [25]. b) GIS building shape file used to construct the building height model.

\section{Tsunami Inundation Mapping}

The computation time for tsunami modeling is 3 hours. In order to satisfy the stability condition, the time step for numerical computation is fixed at $0.2 \mathrm{~s}$. Tsunami inundation is calculated on the fifth domain using $5 \mathrm{~m}$ resolution of bathymetry/topography grid data with $1567 \times 3346$ grid points in the longitude and latitude directions, respectively. Fig. 6 shows synthetic tsunami height recorded at the Callao tide gauge station, which is located at 77.16W, 12.06S (see Fig. 10), within 3 hours of simulation. The tsunami arrival time registered at the Callao station is about $20 \mathrm{~min}$ for both source scenarios, $22 \mathrm{~min}$ and $25 \mathrm{~min}$ for the first and second, respectively. In addition, the time step when maximum tsunami height occurred, which is approximately equal to $38 \mathrm{~min}$ on average, is considered alike for both models. Taking into account, however, that the bathymetry dataset is constant in both numerical simulations, it is certain that there is a difference in tsunami height amplitude, while the maximum tsunami wave height is approximately $5 \mathrm{~m}$ for the first scenario. In the case of the second scenario, it is approximately $10 \mathrm{~m}$. This notable difference is consistent with the initial sea floor displacement due to each source scenarios (Fig. 4). Hence, clear differences regarding tsunami flooding features should be expected.

The local inundation depth is the result of measuring water marks on structures above the ground. Inundation

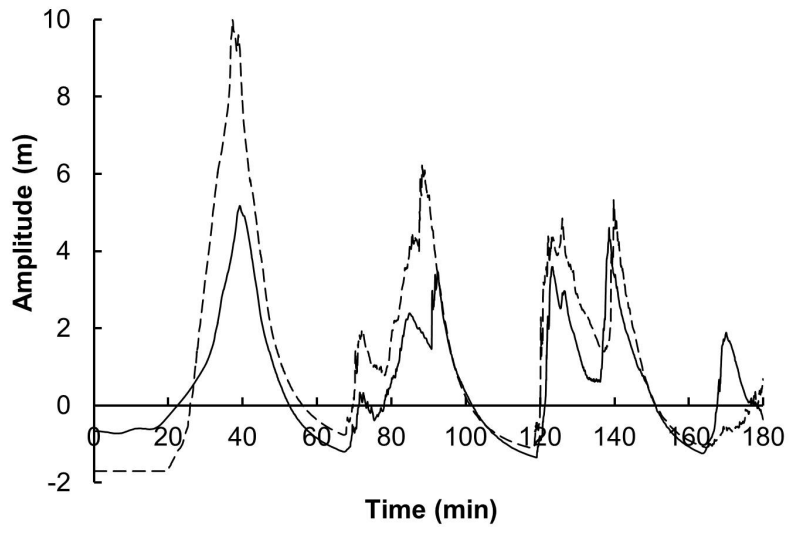

Fig. 6. Synthetic tsunami height recoded at the Callao tide gauge station. The solid line was calculated using the first source scenario [14]. The dashed line was calculated using the second source scenario [16].

depth and inundation area results for each source scenario are shown in Fig. 7. As expected, there is a clear difference in terms of tsunami depth and inundation area between the two scenarios. In terms of inundation depth, its maximum values reach $6 \mathrm{~m}$ and $15.8 \mathrm{~m}$ in the first and second scenarios, respectively. Considering the input of the building height model, the inundation depth in the case of the second scenario therefore completely over flows approximately $95 \%$ of the buiding within the inundation area (see Fig. 7b). In contrats, for the first scenario, only one-storey buildings (approximately 5\%) are completely inundated (see Fig. 7a). In the northern part of the computational domain, inundation distantce reaches a maximum extension of $1 \mathrm{~km}$ with a runup heights of $6 \mathrm{~m}$ for the first scenario. In the case of the second scenario reaches about $1.4 \mathrm{~km}$ with a runup heights of $12.4 \mathrm{~m}$. In the surrounding area of the Rimac river estuary $12^{\circ} 02^{\prime} \mathrm{S}$ latitude tsunami inundation extends up to $1.3 \mathrm{~km}$ with a runup height of $5.3 \mathrm{~m}$ for the first scenario that extends up to $2.1 \mathrm{~km}$ with a runup height of $11.4 \mathrm{~m}$ for the second scenario. Tsunami depth and inundation area characteristics for the southern part of the computational domain (Callao-La Punta area) is discussed later in section 5.2.

\subsection{Tsunami Impact Assessment}

In order to analyze tsunami impact in the study area, we estimated potential tsunami casualties due to tsunami flooding. [27] introduced a practical methodology that uses a simple human model based on cylinder members to evaluate the effect of hydrodynamic force on it. It is thus possible to determine locations and times within the tsunami inundation zone where casualties are likely to occur. [23] presented an improvement on the previous method by considering that human model falls by two different mechanisms. The first considers that hydrodynamic force exceeds friction force on the soles of human model feet (Eq. (7)) and the second occurs when the moment from the bottom back of the heel due to the hydrodynamic force is bigger than the resistance moment due to human model weight (Eq. (8)). 


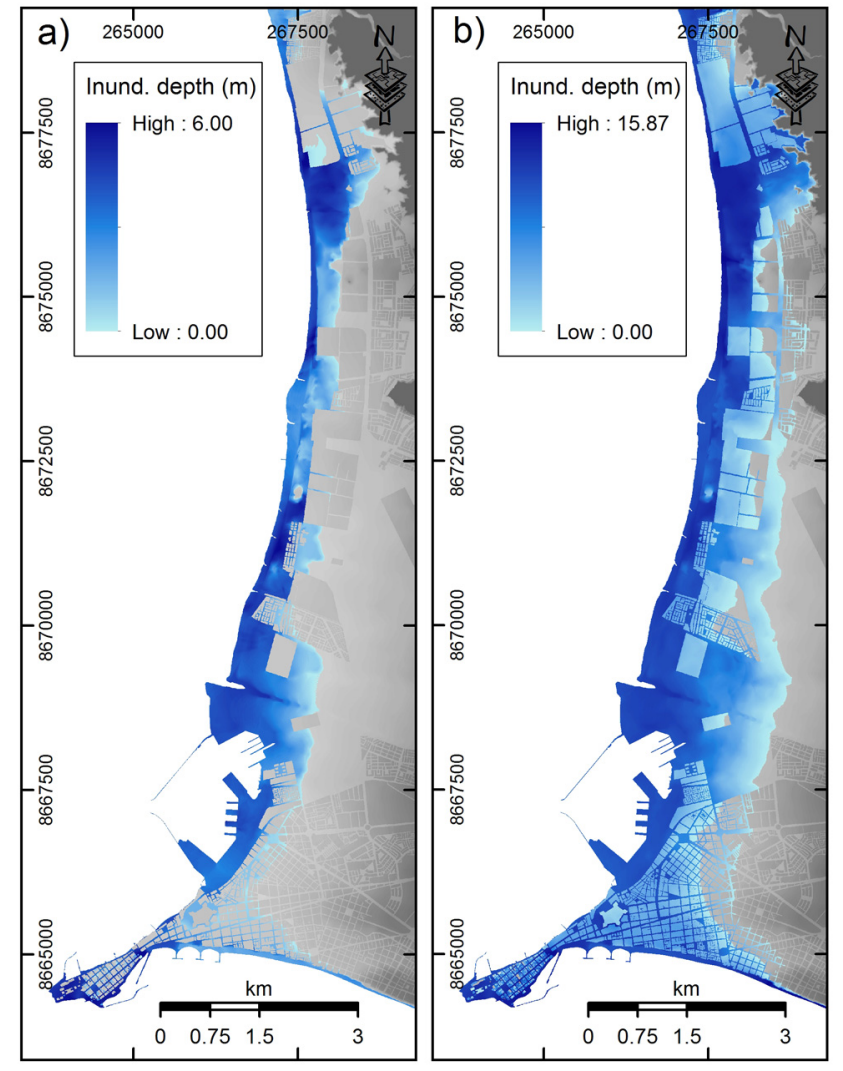

Fig. 7. a) Tsunami inundation calculated using the first source scenario. b) Tsunami inundation calculated using the second source scenario. The inundation depth scale is shown for each model.

$$
\begin{aligned}
\mu\left(W_{0}-W\right) & \leq\left(\int \frac{1}{2} \rho C_{D} u^{2} d S+\int \rho C_{M} \frac{\partial u}{\partial t} d V\right) \\
\cdot & \cdot \cdot \cdot \cdot \cdot \cdot \cdot \cdot \cdot \cdot \cdot \cdot(7) \\
\left(W_{0}-W\right) I_{G} & \leq\left(\int \frac{1}{2} \rho C_{D} u^{2} d S+\int \rho C_{M} \frac{\partial u}{\partial t} d V\right) h_{G}
\end{aligned}
$$

In the above equations, $\mu$ is the friction coefficient, $W_{0}$ is body weight, $W$ is buoyancy, $h_{G}$ is the vertical distance from the floor to the resultant force due to the flow depth, $I_{G}$ is the distance between the center of gravity of the body and the bottom back of the heel, $\rho$ is sea water density, $u$ is velocity, $S$ is the perpendicular projection area according to flow depth, $(\partial u / \partial t)$ is local acceleration, $V$ is the volume of the submerged human body, and $C_{D}$ and $C_{M}$ are drag and inertia coefficients, respectively. [27] introduced a tsunami casualty index (TCI) that is defined by Eq. (9) where $T_{C}$ is the duration of the tsunami inundation flow that satisfies Eqs. (7) and (8) and $T_{i}$ is the total duration of the tsunami inundation flow. TCI is used to illustrate the spatial distribution of potential tsunami casualties.

$$
T C I=\frac{T_{C}}{T_{i}}
$$

In this study, the human body model is shown in Fig. 8. This model is constructed by examining technical reports

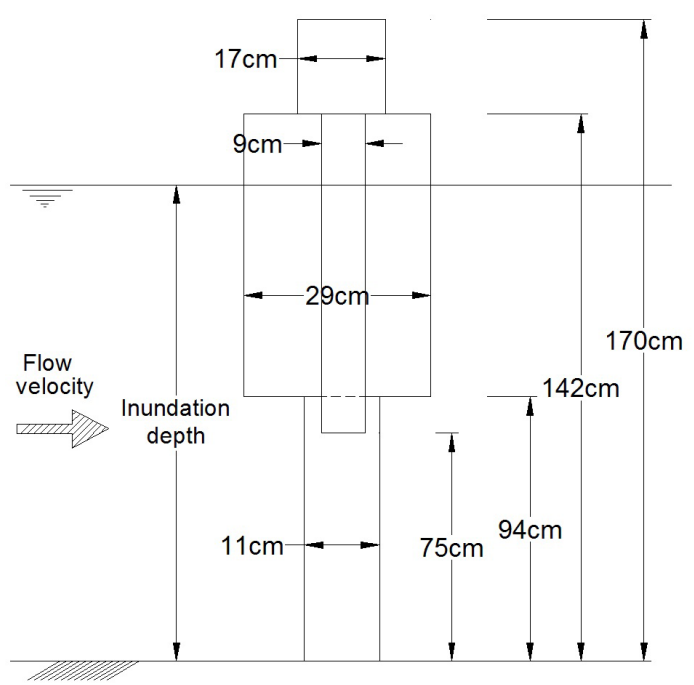

Fig. 8. Schematic explanation and measurements of human model adopted in this study.

elaborated by the Peruvian Health Institute [28], and its measurements are a good physical representation of the average Peruvian adult in Lima. Additionally, the friction coefficient in foot soles is assumed as 0.7 [29] and $C_{D}$ and $C_{M}$ are assumed equal to 1.0 and 0.5 [27], respectively. TCI results for both models are shown in Fig. 9. Basically, the TCI for each model follows consistent behavior similar to inundation depth and inundation area. Based on the impact assessment model, howevaer, in the case of the first scenario, there are areas with inundation depth up to $4 \mathrm{~m}$ for which the TCI shows values of 0.5 (see Fig. 9a), which might indicate that tsunami flow velocity is not strong enough to produce hydrodynamic force able to adversely affect the balance of the human model within 3 hours of tsunami simulation [23]. It is important to note that some of these areas are concentrated in the La Punta district, where the maximum TCI value is 0.52 for most of the streets. The average TCI value obtained for the first scenario is 0.36 throughout the whole inundation domain. In the case of the second scenario, however, approximately $85 \%$ of the inundation area shows TCI values over 0.8 (see Fig. 9b). Specifically, for the La Punta distric, practically $90 \%$ of sreets shows a TCI value of 0.93 . In the case of the second scenario, the mean value for the TCI is 0.64. Additionally, based on our numerical calculation, the balance instability of the human model for each cell grid in almost the whole inundation domain occurs between 2 and 5 minutes after the tsunami wave arrives.

\subsection{Tsunami Mapping for Callao-La Punta}

A comparison of tsunami inundation for the Callao-La Punta area is presented in Fig. 10. Based on numerical results, the second scenario is almost twice that of the first scenario in terms of inundation depth and inundation area. This fact is due to the slip model of each scenario. In the case of the first scenario, inundation depth values reach $6 \mathrm{~m}$, which may inundate one-storey buildings com- 


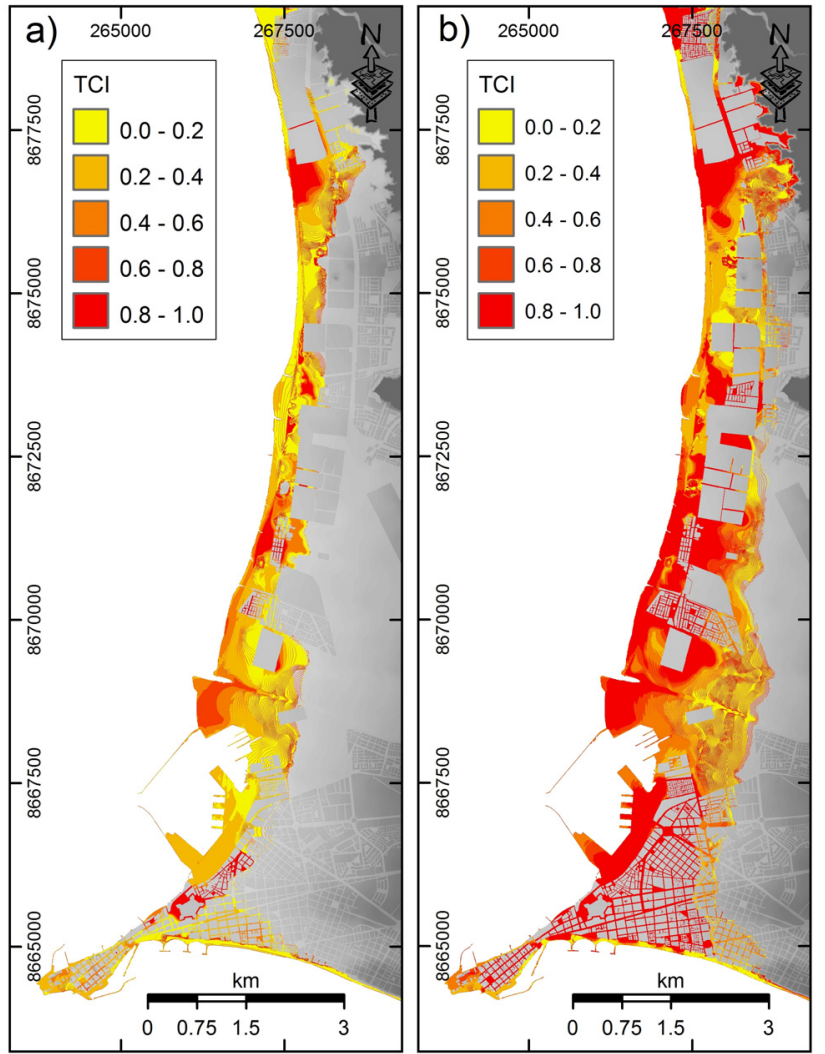

Fig. 9. a) TCI estimated using tsunami feature results from the first source scenario. b) TCI estimated using tsunami feature results from the second source scenario. The TCI scale is shown for each model.

pletely. The inundation depth for most of the streets in the La Punta district reaches values up to approximately $4 \mathrm{~m}$. Based on the time series shows in the previous Fig. 6, however, this state occurs three times with a time period of about 50 minutes in 3 hours of tsunami simulation. Inundation area extends several blocks on land in Callao province (about $1 \mathrm{~km}$ of inundation) with a maximum runup height of $4 \mathrm{~m}$ (see Fig. 10a). In the case of the second scenario, inundation depth reaches $15.8 \mathrm{~m}$, which is why almost $90 \%$ of the buildings are completely inundated. The inundation depth for all of the streets in the La punta district reaches a maximum value of $10.6 \mathrm{~m}$. There are therefore some buildings six stories high that may not be inundated. The inundation area also extends several blocks on land in Callao province (about $2.15 \mathrm{~km}$ inundation) with a maximum runup height of $11 \mathrm{~m}$ (see Fig. 10b). There is a clear inundation zone, however, that extends $1.7 \mathrm{~km}$ and that corresponds to the inundation zone when buildings are completely inundated.

\section{Conclusions}

Tsunami inundation modeling using two different tsunami source scenarios and a detailed bathymetry raster dataset was carried out in order to determine the tsunami
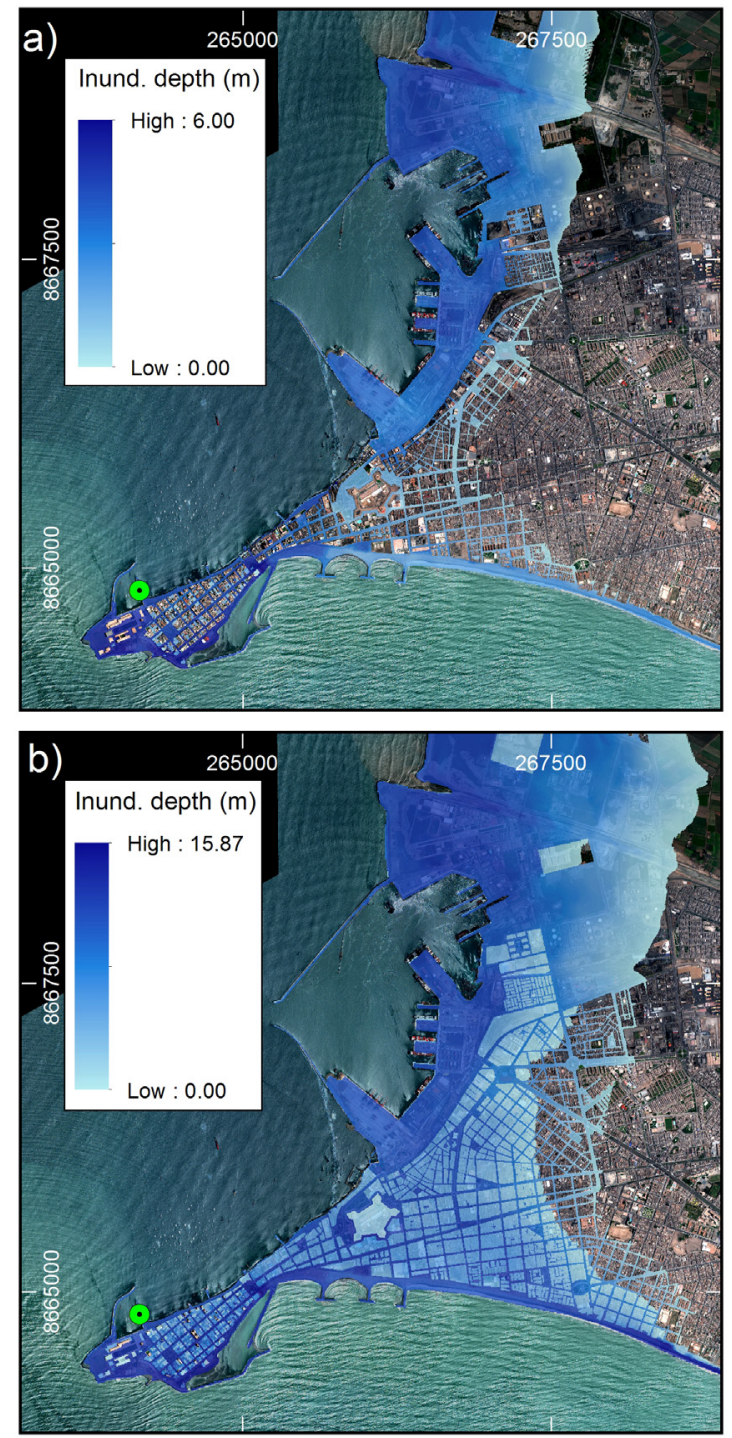

Fig. 10. Comparison of tsunami inundation from both source models for the Callao-La Punta area. a) Inundation mapping using the first source scenario. b) Inundation mapping using the second source scenario. The green circle shows the location of the Callao tide gauge station.

inundation area for the coastal region of Lima city. Additionally, flow depth and flow velocity results were used to evaluate tsunami impact by estimating a tsunami casualty index within the inundation area. Inundation maps developed using both tsunami scenarios show two highly different tsunami risks for the study area. The inundation depth and inundation area for the second scenario (past source scenario) shows most of the tsunami features to be twice the results using the first scenario (potential source scenario). If we therefore consider Peruvian seismic history and lessons learned from past tsunami events in other regions, such as the 2011 Tohoku tsunami, both mapping results should be considered in order to propose a tsunami warning system. Additionally, TCI maps estimated using both scenarios show consistent behavior similar to that shown by the inundation maps. Mean values of 
the TCI in the computation domain are 0.36 and 0.64 for the first and second scenarios, respectively. These TCI maps may be useful for developing tsunami evacuation plans, especially in the case of the La Punta district where the TCI value is greater than 0.5 for both models. Finally, mapping results presented in this paper give important information for understanding tsunami inundation features, and they therefore may be useful in designing an adequate tsunami warning system that can be included in tsunami evacuation plans for Lima city.

\section{Acknowledgements}

The authors acknowledge financial and other support from the Japan Ministry of Education, Culture, Sports, Science and Technology (MEXT) and the project of Science and Technology Research Partnership for Sustainable Development (SATREPS) supported by JST-JICA throughout the study. Such support made possible the forthcoming international conference, as well as international joint research projects and exchange programs with overseas institutions.

\section{References:}

[1] L. Dorbath, A. Cisternas, and C. Dorbath, "Assessment of t h e size of large and great historical earthquakes in Peru," Bulletin of the Seismological Society of America, Vol.80, No.3, pp. 551-576, 1990.

[2] Dirección de Hidrografía y Naveagación, "Cartas de Inundación," 2012.

[3] H. Godoy and J. Monge, "Metodología para la evaluación del riesgo de tsunami. Santiago, Chile," tech. rep., Publicación SES I 3-75, 1975.

[4] A. Delgado and C. García, "Plan de Evacuación de Ciudades Afectadas por Tsunamis, Zona La Punta-Pucusana. Lima," B.s. eng. thesis, National University of Engineering, Peru, 1982.

[5] E. Mas and V. Jacome, "Estudios de tsunamis de origen cercano en el Callao centro-norte, planes de evacuacion y uso de suelo," B.s. eng. thesis, National University of Engineering, Peru, 2008.

[6] PNUD/SDP-052/2009, "Investigación sobre el PELIGRO DE TSUNAMI en el Área Metropolitana de Lima y Callao," in SISTEMA, DE INFORMACIÓN SOBRE RECURSOS PARA ATENCIÓN DE DESASTRES, COOPERAZIONE INTERNAZIONALE COOPI, 2010.

[7] C. Goto and Y. Ogawa, "Numerical Method of Tsunami Simulation with the Leap-frog Scheme. Translated for the TIME project by N. Shuto," 1992.

[8] Instituto Nacional de Estadstica e Informatica (Institute of Statistic and Informatics), "Censos Nacionales 2007," 2007.

[9] S. L. Beck and L. J. Ruff, "Great earthquakes and subduction along the Peru trench," Physics of the Earth and Planetary Interiors, Vol.57, pp. 199-224, Nov. 1989.

[10] T. Sagiya, S. Miyazaki, and T. Tada, "Continuous GPS array and present-day crustal deformation of Japan," Pure and Applied Geophysics, Vol.157, pp. 2303-2322, 2000.

[11] M. Hashimoto, M. Enomoto, and Y. Fukushima, "Coseismic Deformation from the 2008 Wenchuan, China, Earthquake Derived from ALOS/PALSAR Images," Tectonophysics, Vol.491, pp. 5971, Aug. 2010.

[12] W. Liu and F. Yamazaki, "Detection of Crustal Movement From TerraSAR-X Intensity Images for the 2011 Tohoku, Japan Earthquake," IEEE GEOSCIENCE AND REMOTE SENSING LETTERS, Vol.10, No.1, pp. 199-203, 2013.

[13] J. Kuroiwa, "Disaster Reduction, Living in harmony with nature," Lima: Editorial NSG S.A.C, first edit ed., 2004.

[14] N. Pulido, H. Tavera, H. Perfettini, M. Chlieh, Z. Aguilar, S. Aoi, S. Nakai, and F. Yamazaki, "Estimation of Slip Scenarios for Megathrust Earthquakes: A Case Study for Peru," in Effects of Surface Geology on Seismic Motion, pp. 1-6, 2011.

[15] K. Gagnon, C. D. Chadwell, and E. Norabuena, "Measuring the onset of locking in the Peru-Chile trench with GPS and acoustic measurements.," Nature, Vol.434, pp. 205-8, Mar. 2005.
[16] C. Jimenez, N. Moggiano, E. Mas, B. Adriano, S. Koshimura, Y. Fujii, and H. Yanagisawa, "Seismic Source of 1746 Callao Earthquake from Tsunami Numerical Modeling," Journal of Disaster Research, Vol.8, No.2, pp. 266-273, 2013 (this number).

[17] Y. Okada, "Surface deformation due to shear and tensile faults in a half-space," Bulletin of the Seismological Society of America, Vol.75, No.4, pp. 1135-1154, 1985.

[18] F. Imamura, "Review of the tsunami simulation with a finite difference method, Long Wave Run-up Models," World Scientifi, pp. 25$42,1995$.

[19] S. J. Hong, "Study on the Two and Three Dimensional Numerical Analysis of Tsunamis near a coastal Area," Ph.D thesis, Tohoku University, Japan, 2004.

[20] T. Aburaya and F. Imamura, "The proposal of a tsunami runup simulation using combined equivalent roughness," Annual Journal of Coastal Engineering, Japan Society of Civil Engineers, Vol.49, pp. 276-280, 2002.

[21] S. Koshimura and T. Oie, "Developing fragility functions for tsunami damage estimation using numerical model and posttsunami data from Banda Aceh, Indonesia," Coastal Engineering Journal, Vol.51, No.3, pp. 243-273, 2009.

[22] A. Suppasri, S. Koshimura, and F. Imamura, "Developing tsunami fragility curves based on the satellite remote sensing and the numerical modeling of the 2004 Indian Ocean tsunami in Thailand," Natural Hazards and Earth System Science, Vol.11, pp. 173-189, Jan. 2011.

[23] A. Muhari, F. Imamura, S. Koshimura, and J. Post, "Examination of three practical run-up models for assessing tsunami impact on highly populated areas," Natural Hazards and Earth System Science, Vol.11, pp. 3107-3123, Dec. 2011.

[24] G. Gayer, S. Leschka, I. Nöhren, O. Larsen, and H. Günther, "Tsunami inundation modelling based on detailed roughness maps of densely populated areas," Natural Hazards and Earth System Science, Vol.10, pp. 1679-1687, Aug. 2010.

[25] B. Adriano, E. Mas, S. Koshimura, and Y. Fujii, "Remote Sensingbased Assessment of Tsunami Vulnerability in the coastal area of Lima, Peru," in The $10^{\text {th }}$ International Workshop on Remote Sensing for Disaster Management, 2012.

[26] M. Kotani, F. Imamura, and N. Shuto, "Tsunami run-up simulation and damage estimation by using GIS," in Proceedings of coastal engineering, JSCE 45, pp. 356-360, 1998.

[27] S. Koshimura, T. Katada, H. O. Mofjeld, and Y. Kawata, "A method for estimating casualties due to the tsunami inundation flow," Natural Hazards, Vol.39, pp. 265-274, Oct. 2006.

[28] Ministerio de Salud del Peru, "Instituto Nacional de la Salud," 2012.

[29] H. Yeh, "Gender and Age Factors in Tsunami Casualties," Natural Hazards Review, Vol.11, pp. 29-34, Feb. 2010. 


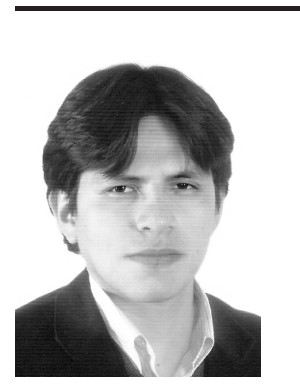

Name:

Bruno Adriano Ortega

\section{Affiliation:}

Research Student, Laboratory of Remote Sensing and Geoinformatics for Disaster Management (ReGiD), International Research Institute of Disaster Science (IRIDeS), Tohoku University

Address:

Aoba 6-6-3, Sendai 980-8579, Japan

Brief Career:

2009-2010 Master of Disaster Management, National Graduate Institute for Policy Studies, Japan

2010-2012 Adjunct Professor, Faculty of Civil Engineering, National

University of Engineering, Peru

2012-present Research Student, ReGiD, IRIDeS, Tohoku University, Japan Selected Publications:

- B. Adriano, E. Mas, S. Koshimura, and Y. Fujii, "Remote Sensing-based Assessment of Tsunami Vulnerability in the coastal area of Lima, Peru," in The $10^{\text {th }}$ International Workshop on Remote Sensing for Disaster

Management, Japan, 2012.

- E. Mas, B. Adriano, S. Koshimura, F. Imamura, J. Kuroiwa, F. Yamazaki, C. Zavala, and M. Estrada, "Evaluation of Tsunami Evacuation Building Demand through the Multi-Agent System Simulation of Residents' Behavior," in Proceedings of International Sessions in Coastal Engineering, JSCE, Vol.3, 2012.

- B. Adriano, S. Koshimura, and Y. Fujii, "Tsunami Source and Inundation Modeling of the June 2001 Peru Earthquake," in Joint Conference

Proceedings 9CUEE/4ACEE, Tokyo, pp. 2061-2065, 2012.

Academic Societies \& Scientific Organizations:

- Peruvian Engineering College

- Japan Geoscience Union (JpGU)

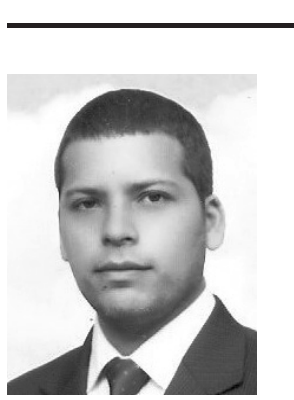

Name:

Erick Mas Samanez

\section{Affiliation:}

Assistant Professor, Laboratory of Remote Sensing and Geoinformatics for Disaster Management (ReGiD), International Research Institute of Disaster Science (IRIDeS), Tohoku University

\section{Address:}

Aoba 6-6-3, Sendai 980-8579, Japan

Brief Career:

1999-2004 B.S. Civil Engineering, National University of Engineering, Peru

2006-2009 M.Sc. Disaster Risk Management, National University of

Engineering, Peru

2009-2012 PhD Civil Engineering, Tsunami Engineering, Tohoku

University, Japan

2012- Assistant Professor, ReGiD, IRIDeS, Tohoku University, Japan

Selected Publications:

- E. Mas, A. Suppasri, F. Imamura, and S. Koshimura, "Agent Based simulation of the 2011 Great East Japan Earthquake Tsunami evacuation. An integrated model of tsunami inundation and evacuation," Journal of Natural Disaster Science, Vol.34, Iss.1, pp. 41-57, 2012.

- E. Mas, S. Koshimura, A. Suppasri, M. Matsuoka, M. Matsuyama, T. Yoshii, C. Jimenez, F. Yamazaki, and F. Imamura, "Developing Tsunami fragility curves using remote sensing and survey data of the 2010 Chilean Tsunami in Dichato," Natural Hazards and Earth System Science, Vol.12, pp. 2689-2697, 2012, doi:10.5194/nhess-12-2689-2012.

Academic Societies \& Scientific Organizations:

- Japan Geoscience Union (JpGU)

- European Geosciences Union (EGU)

- American Geophysical Union (AGU)

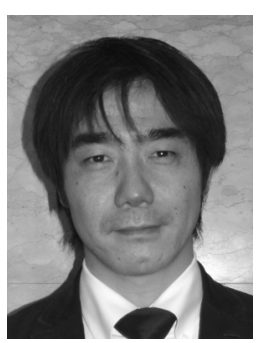

Name:

Shunichi Koshimura

\section{Affiliation:}

Professor, Laboratory of Remote Sensing and Geoinformatics for Disaster Management (ReGiD), International Research Institute of Disaster Science (IRIDeS), Tohoku University

Address:

Aoba 6-6-3, Sendai 980-8579, Japan

Brief Career:

2000-2002 JSPS Research Fellow, National Oceanic and Atmospheric Administration

2002-2005 Research Scientist, Disaster Reduction and Human Renovation Institute

2005-2012 Associate Professor, Tohoku University

2012- Professor, ReGiD, IRIDeS, Tohoku University, Japan

Selected Publications:

- S. Koshimura, T. Oie, H. Yanagisawa, and F. Imamura, "Developing fragility functions for tsunami damage estimation using numerical model and post-tsunami data from Banda Aceh, Indonesia," Coastal Engineering Journal, No.3, pp. 243-273, 2009.

- S. Koshimura, Y. Hayashi, K. Munemoto, and F. Imamura, "Effect of the Emperor seamounts on trans-oceanic propagation of the 2006 Kuril Island earthquake tsunami," Geophysical Research letters, Vol.35, L02611, doi:10.1029/2007GL032129, 24, 2008.

- S. Koshimura, T. Katada, H. O.Mofjeld, and Y. Kawata, "A method for estimating casualties due to the tsunami inundation flow," Natural Hazard Vol.39, pp. 265-274, 2006.

Academic Societies \& Scientific Organizations:

- Japan Society of Civil Engineers (JSCE)

- Institute of Social Safety Science

- Japan Association for Earthquake Engineering (JAEE)

- Japan Society for Computational Engineering and Science (JSCES) - American Geophysical Union (AGU)

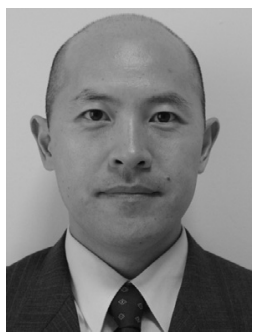

Name:

Yushiro Fujii

\section{Affiliation:}

Senior Research Scientist, International Institute of Seismology and Earthquake Engineering, Building Research Institute

Address:

1 Tachihara, Tsukuba, Ibaraki 305-0802, Japan

Brief Career:

2004 Ph.D. Earth and Planetary Sciences, Faculty of Sciences, Kyushu University, Japan

2005 Researcher, Research Institute for Information Technology, Kyushu University, Japan

2006 Researcher, AFRC, Advanced Industrial Science and Technology

2006- Research Scientist, IISEE, Building Research Institute, Japan

Selected Publications:

- Y. Fujii and K. Satake, "Slip Distribution and Seismic Moment of the 2010 and 1960 Chilean Earthquakes Inferred from Tsunami Waveforms and Coastal Geodetic Data," Pure and Applied Geophysics, 2012.

- Y. Fujii, K. Satake, S. Sakai, M. Shinohara, and T. Kanazawa, "Tsunami source of the 2011 off the Pacific coast of Tohoku Earthquake," Earth, Planets and Space, Vol.63, pp. 815-20, 2011.

- Y. Fujii and K. Satake, "Tsunami Source of the 2004 Sumatra-Andaman Earthquake Inferred from Tide Gauge and Satellite Data," Bulletin of the Seismological Society of America, Vol.97, pp. S192-S207, 2007.

Academic Societies \& Scientific Organizations:

- Seismological Society of Japan (SSJ)

- Japan Geoscience Union (JpGU)

- American Geophysical Union (AGU) 


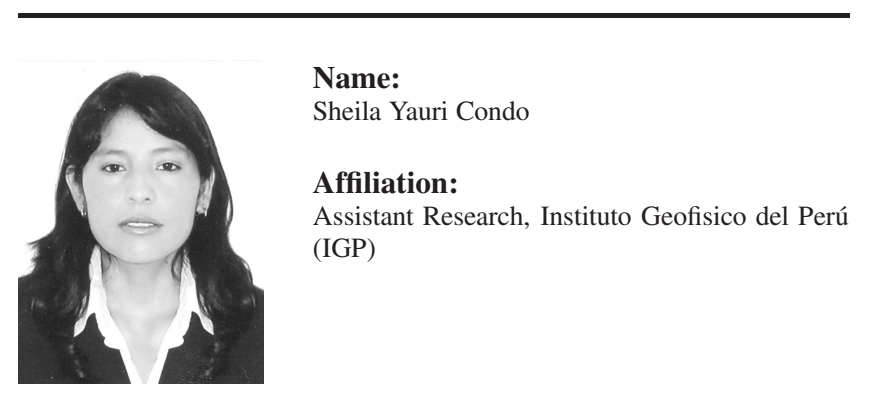

Address:

Calle Badajoz 169, Mayorazgo IV etapa, Ate Vitarte, Perú

Brief Career:

2007-2010 Assistant Researcher, Sección de Seismología, Instituto Geofisico del Perú

2012- Assistant Researcher, Sección de Geofísica y Sociedad, Instituto

Geofisico del Perú

\section{Selected Publications:}

- M. Ioualalen, H. Perfettini, S. Yauri, C. Jimenez, H. Tavera, "Tsunami Modeling to Validate Slip Models of the 2007 Mw8.0 Pisco Earthquake, Central Peru," Pure and Applied Geophysics. 2012.

- S. Yauri, F. Fujii, B. Shibazaki, "Tsunami hazard assessment for the central coast of Peru using numerical simulations for the 1974, 1966 and 1746 earthquakes," Master thesis, National Graduate Institute for Policy Studies, Japan, 2012.

- S. Yauri, H. Tavera, "Caractersticas Generales del Tsunami del 15 de Agosto de 2007. En Tavera, H. (Ed.) El terremoto de Pisco (Peru) del 15 de Agosto de 2007 (7.5 Mw)," Direccin de Sismologs - CNDG / Instituto Geofsico del Per. Volumen Especial, pp. 371-386, 2007.

Academic Societies \& Scientific Organizations:

- Society Geological of Peru (SGP)

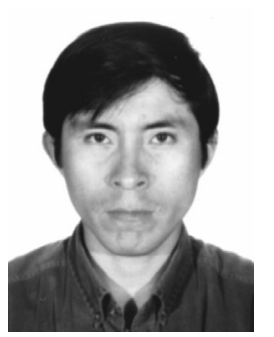

Name:

Cesar Jimenez Tintaya

\section{Affiliation:}

Fenlab, Universidad Nacional Mayor de San Marcos (UNMSM)

Dirección de Hidrografía y Naveagacíon (DHN)

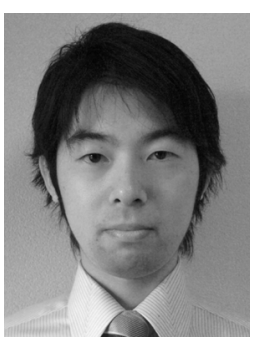

Name:

Hideaki Yanagisawa

\section{Affiliation:}

Department of Regional Management, Faculty of Liberal Arts, Tohoku Gakuin University

\section{Address:}

2-1-1 Tenjinzawa, Izumi-ku, Sendai, Miyagi 981-3193, Japan Brief Career:

2008-2009 Post-Doctoral Research Fellow, Graduate School of Engineering, Tohoku University

2009- Company Member, Tokyo Electric Power Services Company Limited

2012- Lecturer, Department of Regional Management, Faculty of Liberal Arts, Tohoku Gakuin University

\section{Selected Publications:}

- H. Yanagisawa, S. Koshimura, K. Goto, T. Miyagi, F. Imamura, A. Ruangrassamee, and C. Tanavud, "Damage of mangrove forest by the 2004 Indian Ocean tsunami at Pakarang Cape and Namkem, Thailand," Polish Journal of Environmental Studies, Vol.18, No.1, pp. 35-42, 2009. - H. Yanagisawa, S. Koshimura, K. Goto, T. Miyagi, F. Imamura, A. Ruangrassamee, and C. Tanavud, "The reduction effects of mangrove forest on a tsunami based on field surveys at Pakarang Cape, Thailand and numerical analysis, Estuarine," Coastal and Shelf Science, Vol.81, pp. 27-37, 2009 .

Academic Societies \& Scientific Organizations:

- Japan Society of Civil Engineers (JSCE)

- Japan Society for Mangroves

\section{Address:}

Av. Venezuela s/n, Lima, Perú

Calle Roca 116, Chucuito-Callao, Perú

\section{Brief Career:}

2000-2007 Assistant Research, Instituto Geofisico del Perú IGP

2008-2012 Research Scientist, Dirección de Hidrografía y Naveagacíon

2009-2012 Assistant Professor, UNMSM, Perú

2012- Graduate Studies in Geophysics, UNMSM, Perú

\section{Selected Publications:}

- M. Ioualalen, H. Perfettini, S. Yauri, C. Jimenez and H. Tavera,

"Tsunami Modeling to Validate Slip Models of the 2007 Mw8.0 Pisco

Earthquake, Central Peru," Pure and Applied Geophysics. 2012.

- E. Mas, S. Koshimura, A. Suppasri, M. Matsuoka, M. Matsuyama, T. Yoshii, C. Jimenez, et al. (2012). "Developing Tsunami fragility curves using remote sensing and survey data of the 2010 Chilean Tsunami in Dichato," Natural Hazards and Earth System Science, 12, 2689-2697. doi:10.5194/nhess-12-2689-2012.

- T. Yoshii, M. Imamura, M. Matsuyama, S. Koshimura, M. Matsuoka, E. Mas and C. Jimenez. "Salinity in Soils and Tsunami Deposits in Areas Affected by the 2010 Chile and 2011 Japan Tsunamis," Pure and Applied Geophysics, 2012.

Academic Societies \& Scientific Organizations:

- Peruvian Society of Physics (SOPERFI) 